\title{
In vitro assessment of the cytotoxic, DNA damaging, and cytogenetic effects of hydroquinone in human peripheral blood lymphocytes
}

\author{
Karlo Jurica ${ }^{1}$, Irena Brčić Karačonji ${ }^{2}$, Vesna Benković3 ${ }^{3}$, and Nevenka Kopjar ${ }^{2}$ \\ Special Security Operations Directorate, Ministry of the Interior ${ }^{1}$, Institute for Medical Research and Occupational \\ Health $^{2}$, Faculty of Science, University of Zagreb ${ }^{3}$, Zagreb, Croatia
}

[Received in October 2017; Similarity Check in October 2017; Accepted in December 2017]

\begin{abstract}
This study investigated the mechanisms of hydroquinone toxicity and assessed the relationships between its cytotoxic, genotoxic, and cytogenetic effects tested at 8,140 , and $280 \mu \mathrm{g} \mathrm{mL}^{-1}$ in human peripheral blood lymphocytes exposed for $24 \mathrm{~h}$. The outcomes of the treatments were evaluated using the apoptosis/necrosis assay, the alkaline comet assay, and the cytokinesis-block micronucleus (CBMN) cytome assay. The tested hydroquinone concentrations produced relatively weak cytotoxicity in resting lymphocytes, which mostly died via apoptosis. Hydroquinone's marked genotoxic effects were detected using the alkaline comet assay. Significantly decreased values of all comet parameters compared to controls indicated specific mechanisms of hydroquinone-DNA interactions. Our results suggest that the two higher hydroquinone concentrations possibly led to cross-linking and adduct formation. Increased levels of DNA breakage measured following exposure to the lowest concentration suggested mechanisms related to oxidative stress and inhibition of topoisomerase II. At $8 \mu \mathrm{g} \mathrm{mL}{ }^{-1}$, hydroquinone did not significantly affect $\mathrm{MN}$ formation. At 140 and $280 \mu \mathrm{g} \mathrm{mL} \mathrm{m}^{-1}$, it completely blocked lymphocyte division. The two latter concentrations also led to erythrocyte stabilization and prevented their lysis. At least two facts contribute to this study's relevance: (I) this is the first study that quantifies the degree of reduction in total comet area measured in lymphocyte DNA after hydroquinone treatment, (II) it is also the first one on a lymphocyte model that adopted the "cytome" protocol in an MN assay and found that lymphocytes exposure even to low hydroquinone concentration resulted in a significant increase of nuclear bud frequency. Considering the limitations of the lymphocyte model, which does not possess intrinsic metabolic activation, in order to unequivocally prove the obtained results further studies using other appropriate cell lines are advised.
\end{abstract}

KEY WORDS: apoptosis; cytokinesis-block micronucleus "cytome” assay; nuclear buds; primary DNA damage; total comet area

Hydroquinone is an aromatic compound used as a reducing agent, antioxidant, polymerization inhibitor, chemical stabilizer and intermediate, photographic developer, and skin lightening agent in cosmetics and hair dyes (1). Hydroquinone also occurs in some plants as free hydroquinone or as arbutin (hydroquinone $\beta$-Dglucopyranoside) and may therefore be found in many consumer products, such as vegetables, fruits, grains, coffee, tea, beer, and wine (2). Two medicinal herbs, bearberry [Arctostaphylos uva ursi (L.) Spreng] and strawberry tree (Arbutus unedo L.) have attracted particular attention due to their high arbutin content, which is responsible for their antimicrobial, diuretic, and uroantiseptic properties (3-5). Following a bioactivation process with enzyme $\beta$-glucosidase, arbutin is converted to hydroquinone (6). After absorption, free hydroquinone is metabolized in the liver, forming conjugates. Hydroquinone elimination from the human body occurs via urine in the form of hydroquinone

Correspondence to: Prof Vesna Benković, Division of Animal Physiology, Department of Biology, Faculty of Science, University of Zagreb, Rooseveltov trg 6, Zagreb, Croatia. E-mail: vesna@biol.pmf.hr sulphate and glucuronide (7). The amount of free hydroquinone detected in body was less than $2 \%$ of the total arbutin/HQ dose administered and it points to extensive conjugation and rapid excretion (8).

Hydroquinone has been identified as cytotoxic in vitro (9) and potentially genotoxic in vivo (4). Hydroquinone's genotoxicity has been extensively studied but an unambiguous conclusion could not be made. As reviewed by DeCaprio (2), despite no indications for direct mutagenicity, hydroquinone is considered to be responsible for chromosomal aberrations, abnormal mitoses, formation of micronuclei, aneuploidy, and sister chromatid exchanges. While Whysner et al. (10) reported that hydroquinone forms adducts with DNA in vitro, similar adducts do not occur in vivo. Hydroquinone oxidation generates $p$-benzoquinone, which is classified as a carcinogen for rodents and a leukemogen for humans (11). On the other hand, it has been shown that hydroquinone is a very effective inhibitor of lipid peroxidation, which also indicates its antioxidative and therefore antimutagenic properties (12). Treatment of peripheral blood lymphocytes in vitro with subtoxic and 
toxic concentrations of hydroquinone during 24,41 , and 48 hours showed no damage on chromosome structure (9).

The mechanisms that drive the biological effects of hydroquinone, especially at cellular level, have not yet been fully explained. The contradictory results obtained thus far using well-established cytogenetic methods call for further studies, which motivated us to perform this investigation. Its aim was to explore the mechanisms of hydroquinone toxicity and assess the relationships between its cytotoxic, genotoxic, and cytogenetic effects tested at 8,140 , and $280 \mu \mathrm{g} \mathrm{mL}^{-1}$ in human peripheral blood lymphocytes exposed for $24 \mathrm{~h}$. This experimental model was chosen since lymphocytes are primary cells with a stable genome, commonly used for genotoxicity testing in many contemporary studies (13-17). The outcomes of treatment were evaluated using the apoptosis/necrosis assay, the alkaline comet assay, and the cytokinesis-block micronucleus (CBMN) cytome assay. All of these methods are wellestablished in genetic toxicology and have proven useful in studies with different plant extracts or their active constituents (18-26).

Considering that the results of other similar reports regarding hydroquinone toxicity were controversial and difficult to confirm unambiguously, our intention was to re-assess and verify previous observations using a similar study design but with certain changes in the methods applied.

\section{MATERIALS AND METHODS}

\section{Chemicals and reagents}

Hydroquinone (1,4-dihydroxybenzene; CAS Number: 123-31-9) was purchased from Sigma-Aldrich (Steinheim, Germany). If not specified, other chemicals and reagents were obtained from the same supplier.

\section{Blood sampling}

A peripheral blood sample was collected from a healthy male non-smoker (aged 41 years) who was not exposed to any known genotoxic agents and did not undergo any diagnostic or therapeutic irradiations for one year before the study. Written informed consent was obtained from the blood donor. This experiment was part of a research conducted within the preparation of a $\mathrm{PhD}$ thesis of one of the co-authors, and has been approved by the Faculty of Science, University of Zagreb Ethics Committee.

A total of $20 \mathrm{~mL}$ of blood was collected by venepuncture under sterile conditions into blood collection tubes (BD vacutainer, Becton Dickinson, Franklin Lakes, NJ, USA) which contained lithium heparin as an anticoagulant. One portion of blood was immediately used for the lymphocyte isolation, while the other one was used for the CBMN cytome assay.

\section{Isolation of lymphocytes}

Lymphocyte isolation was performed using Histopaque ${ }^{\circledR} 1077$ reagent (Sigma-Aldrich, St. Loius, MO, USA) according to the manufacturer's instructions (27). Whole blood was mixed with an equal volume of cell culture medium (Gibco ${ }^{\circledR}$ RPMI 1640 (1X) medium, Life Technologies, Paisley, UK). Aliquots of diluted blood were carefully layered onto Histopaque ${ }^{\circledR} 1077$ and immediately centrifuged at $400 \times g$ for 30 minutes (Hettich Rotofix 32 centrifuge, Tuttlingen, Germany). Then the layer containing lymphocytes was carefully aspirated and transferred into a centrifuge tube filled with the cell culture medium. This solution was gently mixed and centrifuged at $250 \times \mathrm{g}$ for $10 \mathrm{~min}$. The same procedure was repeated once more. The obtained lymphocyte pellet was resuspended with the cell culture medium using a Pasteur pipette. Lymphocyte viability was checked using trypan blue staining and was over $96 \%$. There were $2.5 \times 10^{5}$ cells per $\mathrm{mL}$ of the suspension. The isolated lymphocytes were then used in the experiments.

\section{Experimental design}

\section{Selection of the tested concentrations}

The tested concentrations were selected adhering to the available literature $(4,28-36)$. The lowest tested concentration of $8 \mu \mathrm{g} \mathrm{mL}^{-1}$ was calculated by taking into account (I) the maximum allowable daily intake of bearberry leaf extract standardized on arbutin (i.e., $800 \mathrm{mg}$ ), (II) the average human body weight of $70 \mathrm{~kg}$, and (III) the fact that $70 \%$ of arbutin is metabolised into hydroquinone (4). Under normal conditions, hydroquinone produced from arbutin is rapidly detoxified. However, we wanted to assess how severe effects could be produced if this entire amount remained available and freely entered into cells. Two higher concentrations of 140 and $280 \mu \mathrm{g} \mathrm{mL}^{-1}$ were calculated based on former reports regarding the safety of bearberry leaf preparations $(35,36)$ which did not find significant cytogenetic effects or increased micronuclei induction in vitro, as well as based on previous related studies $(32,33)$, which tested hydroquinone at millimolar concentrations on a lymphocyte model using the $\mathrm{MN}$ - and comet assay, respectively.

\section{Lymphocyte treatments}

Aliquots of the lymphocyte suspension ( $\mathrm{V}=1 \mathrm{~mL}$ per each replica) were placed in sterile Falcon ${ }^{\circledR}$ tubes (Fisher Scientific, Pittsburgh, PA, USA) and mixed with the tested compound at 8,140 and $280 \mu \mathrm{g} \mathrm{mL}^{-1}$. Non-treated lymphocytes represented negative control. To prepare a positive control sample, lymphocyte suspension was mixed with $1.25 \mu \mathrm{g} \mathrm{mL}^{-1}$ of bleomycin (Nippon Kayaku Co. Ltd., Tokyo, Japan). All of the samples were incubated for $24 \mathrm{~h}$ at $37{ }^{\circ} \mathrm{C}$ in $5 \% \mathrm{CO}_{2}$ humidified incubator (Heraeus Hera 
Cell 240 incubator, Langenselbold, Germany). For each experimental group, duplicate samples were set up. Following treatment, lymphocyte viability was immediately checked (using a double staining procedure with acridine orange and ethidium bromide), and agarose microgels for the alkaline comet assay were prepared.

For the CBMN cytome assay, whole blood was treated for $24 \mathrm{~h}$ at $37^{\circ} \mathrm{C}$ with selected hydroquinone concentrations or bleomycin $\left(1.25 \mu \mathrm{g} \mathrm{mL}^{-1}\right)$ for positive control, according to recommendations for in vitro treatments (37). Afterwards the cell cultures were established and grown for the next $72 \mathrm{~h}$. Then microscopic slides were prepared and subjected to light-microscopic analyses to study cytogenetic outcomes and lymphocyte proliferation.

\section{Fluorescent viability assay with ethidium bromide and acridine orange (EtBr/AO) staining}

As proposed by Duke and Cohen (38), lymphocytes were stained with a mixture of fluorescent dyes $\left[100 \mu \mathrm{g} \mathrm{mL}^{-1}\right.$ EtBr and $100 \mu \mathrm{g} \mathrm{mL}^{-1} \mathrm{AO}$ dissolved in PBS (1:1 v/v)], and immediately analysed under an epifluorescence microscope (Olympus BX51, Tokyo, Japan; 400× magnification). Three independent scorings were performed and a total of 300 lymphocytes per sample per experiment were morphologically evaluated to determine the percentages of viable, apoptotic, and necrotic cells. Viable cells fluoresced brightly green due to the intercalation of AO in their DNA. Dead cells had a dark orange/red stained nucleus due to the binding of EtBr in their DNA. In the early phase of apoptosis, green stained fragmented nuclei were visible, while late apoptosis was characterized by an orange staining of the cytoplasm.

\section{Alkaline comet assay}

The alkaline comet assay was performed according to standard procedure (39), with minor adjustments. To prepare agarose microgels, we used fully frosted precleaned microscope slides (Surgipath ${ }^{\circledR}$, Cambridgeshire, UK) precoated with $0.6 \%$ normal melting point (NMP) agarose. Over this agarose layer we gently pipetted a second layer that was composed of $5 \mu \mathrm{L}$ of the lymphocyte suspension mixed with $0.5 \%$ low melting point (LMP) agarose. The top layer was comprised of $0.5 \%$ LMP agarose. These microgels were subjected to overnight lysis at $4{ }^{\circ} \mathrm{C}$ in a freshly mixed buffer $\left[2.5 \mathrm{~mol} \mathrm{~L}^{-1} \mathrm{NaCl}\right.$ (Kemika, Zagreb, Croatia), $100 \mathrm{mmol} \mathrm{L}^{-1} \mathrm{Na}_{2}$ EDTA, $10 \mathrm{mmol} \mathrm{L}^{-1}$ Tris-HCl, $1 \%$ Na-laurilsarcosinate, $\mathrm{pH}=10$ ] with $1 \%$ Triton $\mathrm{X}-100$ and $10 \%$ dimethyl sulfoxide (Kemika, Zagreb, Croatia). Alkaline denaturation lasted for $20 \mathrm{~min}$ in a freshly prepared buffer $\left(300 \mathrm{mmol} \mathrm{L}^{-1} \mathrm{NaOH}, 1 \mathrm{mmol} \mathrm{L} \mathrm{Na}_{2}^{-1} \mathrm{NaDT}_{\text {, }}\right.$ $\mathrm{pH}=13.0$ ). After denaturation, the microgels were arranged in a horizontal electrophoresis unit filled with the same buffer and subjected to $20 \mathrm{~min}$ of electrophoresis (at $4{ }^{\circ} \mathrm{C}$, $25 \mathrm{~V}$, and $300 \mathrm{~mA}$ ). Using three changes of $0.4 \mathrm{~mol} \mathrm{~L}^{-1}$ Tris- $\mathrm{HCl}$ buffer $(\mathrm{pH}=7.5)$, the microgels were neutralized and washed. Before microscopic analysis, they were stained for 10 minutes with $100 \mu \mathrm{L}$ of EtBr, applied at $20 \mu \mathrm{g} \mathrm{mL}^{-1}$.

One well-trained scorer performed all of the comet measurements on the coded/blinded slides under an epifluorescence microscope (Olympus BX51, Tokyo, Japan; at $200 \times$ magnification), using a computer-based image analysis system with Comet Assay IV ${ }^{\mathrm{TM}}$ software (Perceptive Instruments Ltd., UK). A total of 200 randomly selected comets per each tested concentration (or control) were measured on replicate slides in two independent evaluations. As indicators of DNA damage, tail length (presented in micrometres), tail intensity (i.e., DNA\% in tail), and total area (it represents the overall surface area of the comet) were chosen.

\section{Cytokinesis-block micronucleus (CBMN) cytome assay}

We applied a standard protocol for the MN assay as recommended by Fenech and Morley (40). For each experimental group, duplicate cultures were set up by adding blood into Gibco ${ }^{\circledR}$ RPMI 1640 (1X) medium (Life Technologies, Paisley, UK) supplemented with inactivated foetal calf serum (Gibco ${ }^{\circledR}$, Invitrogen, Paisley, UK), phytohemagglutinin (Remel Europe Ltd., Dartford, UK), and antibiotics - penicillin and streptomycin solution (Sigma-Aldrich, Steinheim, Germany). Cultures were kept at $37{ }^{\circ} \mathrm{C}$ in sterile flasks $\left(25 \mathrm{~cm}^{2}\right)$, in $5 \% \mathrm{CO}_{2}$ humidified incubator (Heraeus Hera Cell 240 incubator, Langenselbold, Germany). At the $44^{\text {th }}$ hour, the cytokinesis blocking agent cytochalasine B (Sigma-Aldrich, St. Louis, MO, USA) was added $\left(6 \mu \mathrm{g} \mathrm{mL}^{-1}\right)$. After $72 \mathrm{~h}$ of in vitro growth, cultures were harvested by standard procedures including incubation in hypotonic potassium chloride (Kemika, Zagreb, Croatia) solution, and several repetitions of fixation and centrifugation (Hettich Rotofix 32 centrifuge, Tuttlingen, Germany) to obtain lymphocyte suspension. We used an ice-cold fixative made up of 1 part acetic acid (Kemika, Zagreb, Croatia) to 3 parts methanol (Kemika, Zagreb, Croatia). Lymphocyte suspension was dropped onto clean slides. Air-dried slides were stained with $5 \%$ Giemsa solution (Merck, Darmstadt, Germany) for 10 minutes at room temperature. Microscopic analysis was carried out under a light microscope (Leitz, Wetzlar, Germany) at 1000× magnification (oil immersion).

The identification and scoring of micronuclei $(\mathrm{MN})$, nuclear buds (NB), nucleoplasmic bridges (NPB), and apoptotic and necrotic cells was performed using criteria recommended by Fenech et al. (41). A total of 2000 binucleated $(\mathrm{BN})$ cells was examined for each treatment (1000 BN cells per each replica). The same slides were used to study the nuclear division index (NDI), by screening 1000 cells per sample (500 cells per slide). To calculate the NDI, we used the formula proposed by Eastmond and Tucker (42), NDI $=(\mathrm{M} 1+2 \mathrm{M} 2+3 \mathrm{M} 3+4 \mathrm{M} 4) / \mathrm{N}$, where M1-M4 denote the number of cells with 1-4 nuclei, respectively, and $\mathrm{N}$ is the number of cells scored. 


\section{Statistical analysis}

The data were analysed using Dell ${ }^{\mathrm{TM}}$ Statistica ${ }^{\mathrm{TM}} 13.2$ software (Dell Inc., Tulsa, OK, USA). For each data set, basic descriptive statistical parameters such as mean, standard deviation, standard error, median, and minimum and maximum values were determined. To test the normality of distribution, we used Shapiro-Wilks Normality Test. The data obtained with alkaline comet assay were logarithmically transformed to normalise the distribution and equalise variances. Multiple comparisons between groups were performed using analysis of variance (ANOVA) on logtransformed data with the Scheffe's post-hoc test. Comparisons between values obtained for lymphocyte viability, $\mathrm{CBMN}$ assay, and lymphocyte proliferation were conducted using Pearson's $\chi^{2}$-test. The level of statistical significance was set at $\mathrm{p}<0.05$.

\section{RESULTS}

\section{Lymphocyte viability}

The results obtained using dual ethidium bromide/ acridine orange staining showed a concentration-dependent cytotoxicity in all of the hydroquinone-treated samples. At the two higher concentrations lymphocyte viability was significantly lower than in negative control (Table 1). However, as the highest tested concentration caused only $13 \%$ of dead cells, one could emphasize that at the applied in vitro settings hydroquinone had low cytotoxic potential. Majority of cells died via apoptosis, which dominated over necrosis at the two higher hydroquinone concentrations. Treatment with the lowest hydroquinone concentration caused the same proportion of apoptotic and necrotic cells.

\section{Primary DNA damage in peripheral blood lymphocytes estimated by the alkaline comet assay}

Results regarding primary DNA damage levels in peripheral blood lymphocytes measured by the alkaline comet assay, and detailed explanations of their statistical significance are shown in Table 2. Control lymphocytes had low levels of spontaneous primary DNA damage. Twentyfour-hour treatment with all of the three hydroquinone concentrations caused statistically significant deviations in almost all of the comet parameters evaluated. As we expected, the highest values for all of the comet parameters were measured in the positive control sample, which is in agreement with the mechanism of hydrogen peroxide action to DNA.

The most prominent change observed after 24-hour treatment was a significantly decreased comet total area in all of the samples treated with hydroquinone compared to negative control. It is worth to mention that the comets measured in the sample treated with $8 \mu \mathrm{g} \mathrm{mL}-1$ of hydroquinone had more than a 2 -fold lower mean total area compared to those measured in the negative control. Treatment with $140 \mu \mathrm{g} \mathrm{mL}^{-1}$ lowered this value by almost 3.7-fold, while comets measured in the sample treated with $280 \mu \mathrm{g} \mathrm{mL}^{-1}$ of hydroquinone had a 4.3-fold lower mean total area compared to those measured in the negative control. To further document this observation, we calculated the average reduction of the total comet area after hydroquinone treatments with respect to the control cells and these results are shown in Figure 1.

The appearances of lymphocyte nucleoids treated with hydroquinone observed under fluorescence microscope after staining with ethidium bromide are displayed in Figure 2. It should be noted that DNA in the hydroquinone-treated samples was more condensed than the DNA in the negative control.

\section{Cytokinesis-block micronucleus cytome assay}

At two higher concentrations tested, hydroquinone impaired the in vitro growth of short-term lymphocyte cultures, which made it impossible to accomplish the testing and obtain valuable slides for the microscopic analysis in the CBMN cytome assay.

Table 1 Results of the quantitative fluorescent assay for simultaneous identification of apoptotic and necrotic cells in peripheral blood lymphocytes treated with hydroquinone in vitro for $24 \mathrm{~h}$ and in the negative and positive control samples

\begin{tabular}{|c|c|c|c|}
\hline Experimental group & Viable cells $(\%)$ & Apoptosis (\%) & Necrosis (\%) \\
\hline Hydroquinone $8.0 \mu \mathrm{g} \mathrm{mL}^{-1}$ & $93.3 \pm 1.5$ & $3.3 \pm 1.5$ & $3.3 \pm 0.6$ \\
\hline Hydroquinone $140 \mu \mathrm{g} \mathrm{mL}^{-1}$ & $90.3 \pm 2.1^{\mathrm{nc}}$ & $6.3 \pm 1.5$ & $3.3 \pm 0.6$ \\
\hline Hydroquinone $280 \mu \mathrm{g} \mathrm{mL}^{-1}$ & $87.0 \pm 2.6^{\mathrm{nc}, \mathrm{hl}}$ & $8.3 \pm 1.5^{\mathrm{nc}, \mathrm{h} 1}$ & $4.7 \pm 1.5$ \\
\hline Negative control & $95.0 \pm 0.0$ & $3.0 \pm 1.0$ & $2.0 \pm 1.0$ \\
\hline Positive control & $66.0 \pm 7.0 *$ & $16.7 \pm 3.2 *$ & $17.3 \pm 3.8^{*}$ \\
\hline
\end{tabular}




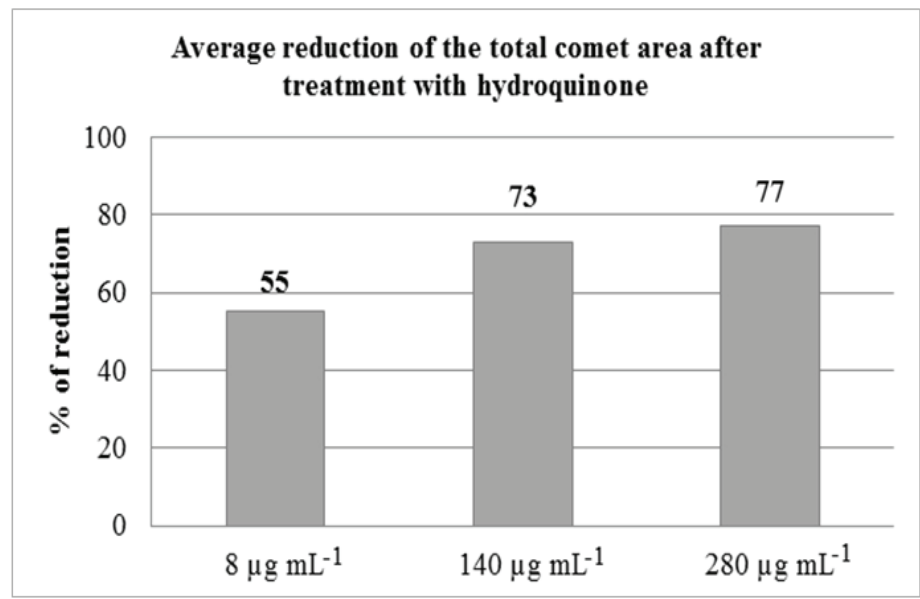

Figure 1 Average reduction of the total comet area observed after $24 \mathrm{~h}$ in vitro treatment of peripheral blood lymphocytes with hydroquinone applied at three concentrations (percentage of reduction was calculated with respect to the mean total comet area measured in the negative control cells)

As shown in Figure 3, despite repeated centrifugation and rinsing of the cell pellets, it was not possible to obtain lymphocyte suspensions. Microscopic analysis of the obtained cell suspensions showed the presence of a large number of erythrocytes that were not lysed during the sample processing, and almost no lymphocytes. Such a result suggests a specific mechanism of hydroquinone action on erythrocyte membranes, which will be discussed later on.

Results of the CBMN cytome assay suggest a low potential of hydroquinone to induce micronuclei at $8 \mu \mathrm{g} \mathrm{mL}^{-1}$ (Table 3). However, at the same concentration hydroquinone showed significant potential towards the formation of nuclear buds (NBs). One of the most typical examples of NB appearance visible under the light microscope is shown in Figure 4a. There were no statistically significant increases in the number of apoptotic and necrotic cells with respect to negative control. As anticipated, positive control (bleomycin) had the highest value for all parameters of the CBMN cytome assay, which confirms the sensitivity and specificity of the method used (Table 3).

\section{Lymphocyte proliferation analysis}

Results regarding lymphocyte proliferation in cell cultures treated in vitro with $8.0 \mu \mathrm{g} \mathrm{mL}^{-1}$ of hydroquinone and in the corresponding negative and positive controls are reported in Table 4. At the concentration tested, hydroquinone

Table 2 Primary DNA damage in peripheral blood lymphocytes treated for $24 \mathrm{~h}$ with hydroquinone applied at three concentrations as determined by alkaline comet assay. Negative and positive controls were studied in parallel. Data are reported as mean $\pm S E$ (first row), median (second row), and range (third row)

\begin{tabular}{lccc}
\hline Experimental group & Tail length $(\mu \mathrm{m})$ & Tail intensity $(\mathbf{D N A} \%)$ & Total area \\
\hline Hydroquinone $8.0 \mu \mathrm{g} \mathrm{mL}^{-1}$ & $16.66 \pm 0.68^{\mathrm{nc}}$ & $2.43 \pm 0.27^{\mathrm{nc}}$ & $315.29 \pm 12.29^{\mathrm{nc}}$ \\
& 15.21 & 0.86 & 282.73 \\
& $5.00-80.83$ & $0.00-24.61$ & $68.40-1102.78$ \\
\hline Hydroquinone $140 \mu \mathrm{g} \mathrm{mL}^{-1}$ & $8.11 \pm 0.21^{\mathrm{nc}}$ & $0.21 \pm 0.05$ & $188.89 \pm 4.56^{\mathrm{nc}}$ \\
& 7.50 & 0.00 & 181.16 \\
& $4.17-23.75$ & $0.00-5.90$ & $82.99-570.83$ \\
\hline Hydroquinone $280 \mu \mathrm{g} \mathrm{mL}^{-1}$ & $6.89 \pm 0.17^{\mathrm{nc}}$ & $0.05 \pm 0.02^{\mathrm{nc}}$ & $159.69 \pm 4.92^{\mathrm{nc}}$ \\
& 6.25 & 0.00 & 147.83 \\
& $3.75-16.67$ & $0.00-2.13$ & $60.42-565.80$ \\
\hline & $17.28 \pm 0.24$ & $0.79 \pm 0.10$ & $693.80 \pm 7.45$ \\
Negative control & 16.25 & 0.03 & 682.99 \\
& $12.08-27.08$ & $0.00-7.44$ & $475.69-1002.08$ \\
\hline
\end{tabular}

Positive control: hydrogen peroxide $\left(\mathrm{H}_{2} \mathrm{O}_{2}\right)$ applied at $100 \mu \mathrm{mol} \mathrm{L} \mathrm{L}^{-1}$ on cells embedded into an agarose microgel for 10 minutes on ice; For each sample, duplicate slides were prepared and two hundred independent comet measurements per sample per experimental point were performed; Statistical significance of data was evaluated using descriptive statistics, ANOVA with post-hoc Scheffe's test; The level of statistical significance was set at $P<0.05$. The abbreviations above the whiskers indicate which groups differ with statistical significance from negative control ( $n c)$, or all other groups (*) 

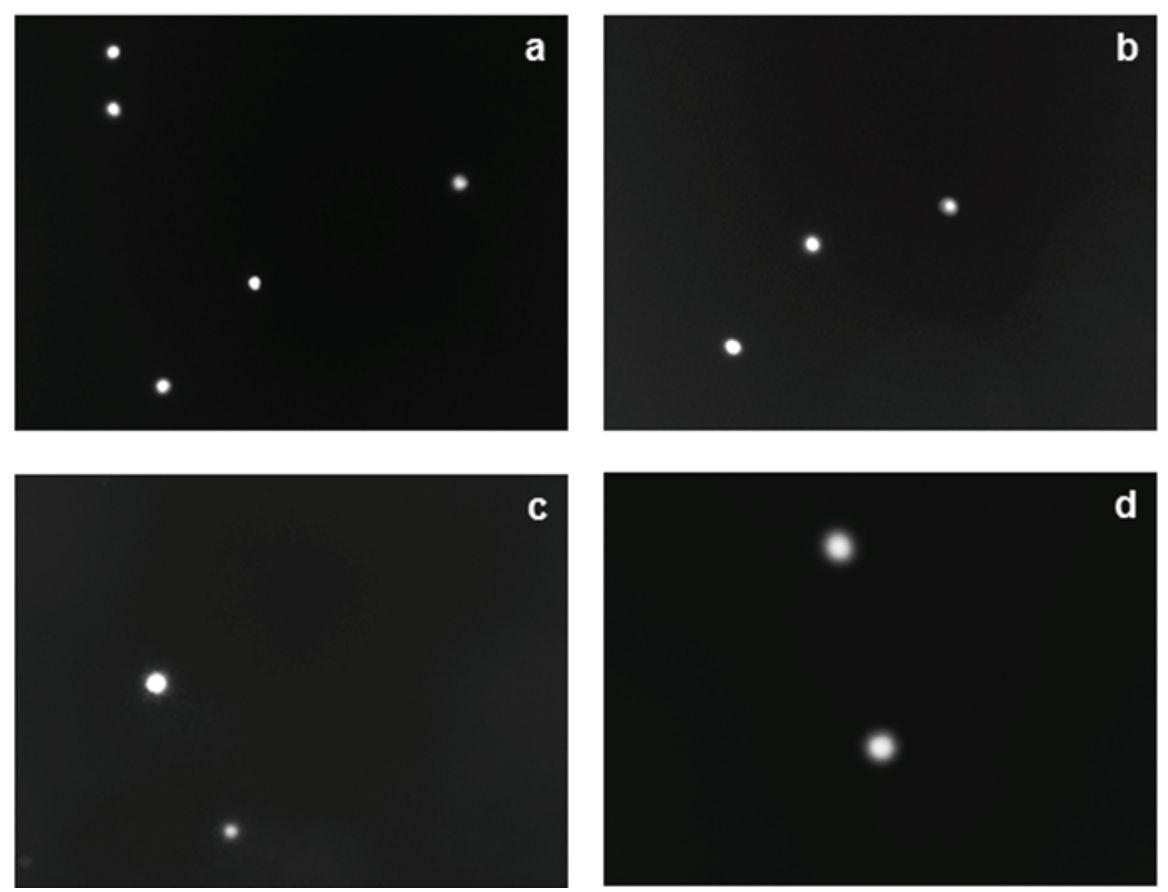

Figure 2 Photomicrographs of lymphocyte nucleoids observed after the alkaline comet assay procedure [(a) at hydroquinone concentration of $280 \mu \mathrm{g} \mathrm{mL} L^{-1}$; (b) at hydroquinone concentration of $140 \mu \mathrm{g} \mathrm{mL} L^{-1}$; (c) at hydroquinone concentration of $8 \mu \mathrm{g} \mathrm{mL} L^{-1}$; (d)

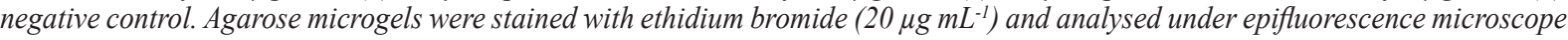
(Olympus BX51, Japan), under magnification $200 \times$. Photomicrographs acquired by image analysis system Comet Assay IV ${ }^{T M}$ (Perceptive Instruments Ltd., Suffolk, UK)]

impaired lymphocyte proliferation and significantly lowered the nuclear division index (NDI) value compared to negative control. The most prominent was a delay of the lymphocyte cell cycle in M2, which resulted in a significantly lower proportion of M3 cells, as well as a complete absence of M4 cells.

\section{DISCUSSION}

Although hydroquinone toxicity has been studied in various experimental models thus far, which distinguishes ours from other previously conducted studies with human lymphocytes is its comprehensive design, which coupled cell viability assessment with the alkaline comet assay and CBMN cytome assay to establish the relationship between the cytotoxic, genotoxic, and cytogenetic effects of the tested compound. Here we will briefly list the added value of our findings. (I) This study is the first to quantify the degree of reduction in the total comet area measured in lymphocyte DNA after hydroquinone treatment, a parameter which the foregoing comet assay studies did not take into account when explaining the mechanisms behind the infliction of primary DNA damage caused by this compound. Based on our observations, the evaluation of this particular comet parameter (which points both to the changes in the overall surface area of the comet and to the impairments in the denaturation step) can be suggested in those cases where chemicals with hydroquinone-related mechanisms of action at DNA level are studied using the conventional alkaline comet assay procedure. (II) None of the studies conducted so far with the lymphocyte MN assay adopted a "cytome" protocol, to simultaneously evaluate the incidence of other cytogenetic changes, such as nuclear buds and nucleoplasmic bridges, apart from micronuclei. The present study was the first one which reports the results of a CBMN cytome assay and found that exposure of lymphocytes to even low hydroquinone concentration results in a significant increase of nuclear bud frequency. Aside from what this study added to the existing knowledge on the subject, it also confirmed observations by other authors regarding MN induction, disturbed lymphocyte cell cycle, toxic effects of hydroquinone, and the mechanisms behind its genotoxicity at cell level. The practical significance of each result will be discussed below in more detail.

When all of the obtained results are taken into account, we can say that two of hydroquinone's effects raised the most concern: (I) a significant amount of specific primary DNA damage as suggested by the values of alkaline comet assay parameters at all of the tested concentrations, and (II) a significant impairment of lymphocyte growth in vitro, especially at the two higher concentrations. We believe these findings are particularly important from the toxicological point of view because of the fact that human exposure to hydroquinone in some cases can be relatively high. Besides occupational exposure, which is limited to specific work settings (e.g., production of hydroquinone, photographic developers, rubber, and other products that contain hydroquinone), there are many sources of 


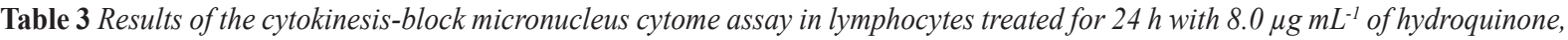
as well as in the negative and positive control samples

\begin{tabular}{|c|c|c|c|}
\hline Parameter & $\begin{array}{c}\text { Negative } \\
\text { control }\end{array}$ & $\begin{array}{c}\text { Hydroquinone } \\
8.0 \mu \mathrm{g} \mathrm{mL}^{-1}\end{array}$ & $\begin{array}{l}\text { Positive } \\
\text { control }\end{array}$ \\
\hline \multicolumn{4}{|c|}{ Distribution of BN cells according to number of micronuclei (MN) } \\
\hline 0 & 1990 & 1991 & 1969 \\
\hline 1 & 9 & 10 & 23 \\
\hline 2 & 0 & 0 & 5 \\
\hline 3 & 0 & 0 & 2 \\
\hline 4 & 0 & 0 & 1 \\
\hline $\mathrm{BN}_{\mathrm{MN}}$ cells $(\% \pm \mathrm{SD})$ & $4.5 \pm 0.7$ & $5.0 \pm 0.0$ & $15.5 \pm 2.1 *$ \\
\hline No. of MN $($ Mean \pm SD) & $4.5 \pm 0.7$ & $5.0 \pm 0.0$ & $21.5 \pm 3.5$ \\
\hline \multicolumn{4}{|c|}{ Distribution of BN cells according to number of NBs } \\
\hline 0 & 1995 & 1985 & 1990 \\
\hline 1 & 5 & 15 & 10 \\
\hline $\mathrm{BN}_{\mathrm{NB}}$ cells $(\% \pm \pm \mathrm{SD})$ & $2.5 \pm 0.7$ & $7.5 \pm 0.7^{\mathrm{nc}}$ & $5.0 \pm 0.0$ \\
\hline No. of NB $($ Mean \pm SD) & $2.5 \pm 0.7$ & $7.5 \pm 0.7$ & $5.0 \pm 0.0$ \\
\hline \multicolumn{4}{|c|}{ Distribution of BN cells according to number of NPBs } \\
\hline 0 & 2000 & 2000 & 1997 \\
\hline 1 & 0 & 0 & 3 \\
\hline $\mathrm{BN}_{\mathrm{NPB}}$ cells $(\% 0 \pm \mathrm{SD})$ & 0 & 0 & 0 \\
\hline No. of NPB $($ Mean \pm SD $)$ & 0 & 0 & $1.5 \pm 0.7$ \\
\hline Apoptotic cells $(\% \pm \pm \mathrm{SD})$ & $1.0 \pm 0.0$ & $2.5 \pm 0.7$ & $2.5 \pm 0.7$ \\
\hline Necrotic cells $(\% \neq \pm \mathrm{SD})$ & 0 & $2.0 \pm 1.4$ & $4.0 \pm 0.0$ \\
\hline
\end{tabular}

$B N$-binucleated cells; $B N_{M N}$ cells - binucleated cells with micronuclei $B N_{N B}$ cells-binucleated cells with nuclear buds; $B N_{N P B} c e l l s$ - binucleated cells with nucleoplasmic bridges; Positive control-lymphocytes treated for $24 \mathrm{~h}$ in vitro with bleomycin at $1.25 \mu \mathrm{g} m L^{-1}$; Microscopic evaluation was performed using a light microscope at $1000 \times$ magnification (oil immersion); To establish the MN frequencies, $2 \times 1000$ cells were scored. Data are expressed as mean $\pm S D$ of two independent evaluations; Statistical significance of the results was evaluated using $\chi^{2}$ test. The level of statistical significance was set at $P<0.05$. For each exposure time intergroup comparisons were also done. The abbreviations next to the means indicate from which groups the relevant group differs with statistical significance: * - vs. all samples; $n c$ - vs. negative control

hydroquinone in otherwise "unexposed" people, which include smoking, consumption of different foods and beverages, use of various herbal preparations and over-thecounter medicines (for instance paracetamol or acetaminophen), as well as the catabolism of proteins (especially the amino acid tyrosine) and other substrates by microorganisms in the digestive system $(2,8,43)$. An example of a food item very rich in free hydroquinone is pear, with $0.02-0.05 \mu \mathrm{g} \mathrm{g}^{-1}(8)$. A threat also arises not only from excessive intake of free hydroquinone, but also from excessive consumption of various items containing its glycoside arbutin. Some herbal preparations like bearberry and strawberry tree leaf extracts also contain significant amounts of arbutin $(4,44)$. Furthermore, an additional route of exposure to arbutin is the dermal one, via application of cosmetics preparations, especially creams used for skin whitening (45-47). The use of arbutin preparations has steadily increased after hydroquinone administration for the same purposes was banned by $24^{\text {th }}$ Directive $2000 / 6$ / EC of the European Parliament (48).

Acute exposure is not associated with significant human health risk, considering that hydroquinone undergoes rapid metabolism to glucuronide and sulphate ester conjugates (2) and has no potential for accumulation in an organism. The amount of free hydroquinone in tissues and organs is less than $2 \%$ of the total arbutin/hydroquinone dose administered (8). However, repeated exposure is a matter of concern and this is why the use of herbal preparations like bearberry leaf extract should be limited to short periods of time (4).

Most studies with hydroquinone conducted so far, including ours, tested the effects of quite high hydroquinone concentrations, considering that the maximum exposure level to free hydroquinone after ingestion of a therapeutic daily dose of bearberry leaf preparation (containing $420 \mathrm{mg}$ of arbutin) is estimated to be $11 \mu \mathrm{g} \mathrm{kg}^{-1}$ b.w. day-1 (8). Roughly, if we convert $\mathrm{kg}$ to $\mathrm{L}$, this dose corresponds to a concentration of $0.011 \mu \mathrm{g} \mathrm{mL}-1$.

Interestingly, by testing much higher hydroquinone concentrations, we observed a relatively weak cytotoxicity in lymphocytes. This was not a surprise, considering that lymphocytes are "stuck" in the $\mathrm{G}_{0}$ phase of the cell cycle, characterized by the slowing down of many intracellular processes $(49,50)$. The majority of dead cells we detected 


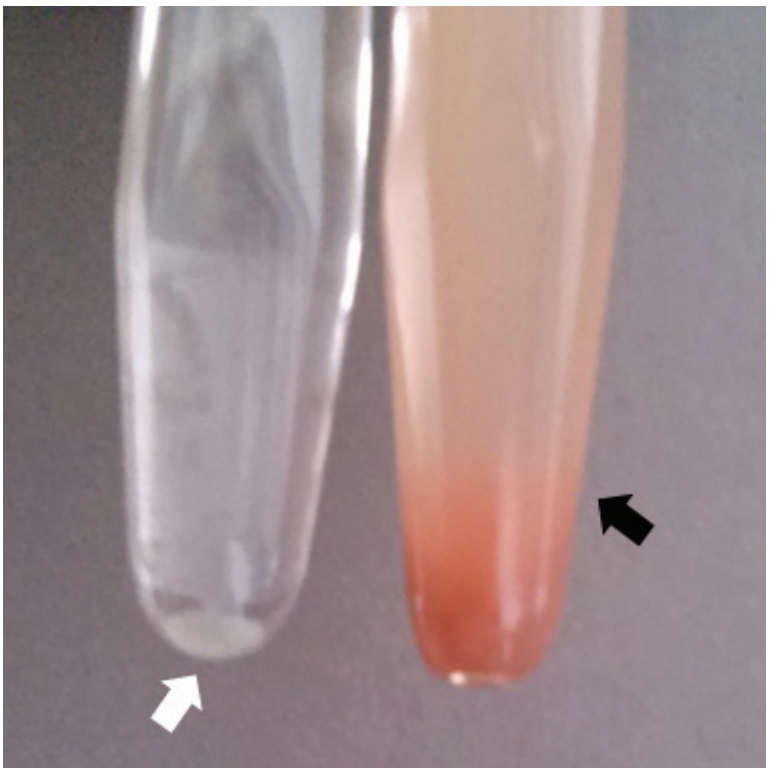

Figure 3 Preparation of lymphocyte samples for CBMN Cytome assay [At the bottom of the left tube a cell pellet, obtained by repeated fixation (with ice-cold fixative made up of 1 part acetic acid to 3 parts methanol) and centrifugation of negative control lymphocyte sample is shown (white arrow). The right tube shows the lymphocyte sample exposed for $24 \mathrm{~h}$ to $140 \mu \mathrm{g} \mathrm{mL^{-1 }}$ of hydroquinone which was handled by the same procedure, however, it was not possible to lyse and remove erythrocytes from the cellular sediment (black arrow)]

using $\mathrm{EtBr} / \mathrm{AO}$ staining died via apoptosis. We assume that cells which possibly contained highly damaged DNA following treatment initiated mechanisms of controlled self-killing. However, due to methodological constrains, we were not able to deduce which exact mechanisms were responsible for hydroquinone-induced apoptosis in our experiment since the double fluorescence staining assay used in the present study permits only the morphological discrimination of dead cells. Therefore, we cannot propose the precise mechanisms behind apoptosis, and if the same experiment is repeated or expanded in the future, this has to be explained using more sophisticated methods for apoptosis detection/characterization. However, the mechanisms underlying hydroquinone cytotoxicity have been explored in several studies on other model systems. Hiraku and Kawanishi (51) observed that apoptosis in hydroquinone- and benzoquinone-treated HL-60 cells was potentiated by internucleosomal DNA fragmentation caused mostly by oxidative DNA damage. Inayat-Hussain et al. (52) found that hydroquinone caused apoptosis by different mechanisms of HL-60 promyelocytic leukaemia cells (via caspase-independent pathways) and in myeloperoxidasedeficient Jurkat T-lymphoblastic leukaemia cells (via caspase activation). Terasaka et al. (53) found that treatment of HL-60 cells with hydroquinone caused the release of cytochrome $\mathrm{c}$ and activation of procaspase- 3 and -9 , suggesting that hydroquinone activates the intrinsic pathway of apoptosis. Yang et al. (54) found that hydroquinone strongly induces apoptosis in neutrophils and eosinophils through the caspase 9/3-dependent pathway and the increased production of reactive oxygen species. Lee at al. (55) reported that the same caspase $9 / 3$ pathway was responsible for hydroquinone-induced human lymphocyte apoptosis.

Despite the relatively low cytotoxicity in resting lymphocytes, this study found marked genotoxic effects of hydroquinone. To estimate the levels of primary DNA damage in hydroquinone-treated lymphocytes, we used an alkaline version of the comet assay, which detects the widest range of lesions (56-58). First literature reports regarding hydroquinone effects detected by the comet assay in peripheral blood lymphocytes treated in vitro originated from Andreoli et al. (59) who found that hydroquinone, along with two other benzene metabolites - benzoquinone and benzenetriol - exerted a significant genotoxic effect on resting lymphocytes, with the lowest effective concentrations below $1 \mu \mathrm{g} \mathrm{mL}^{-1}$.

Our genotoxicity assessment in lymphocyte model was focused on three comet parameters: tail length, tail intensity, and total area, all of which were simultaneously measured by the Comet Assay IV ${ }^{\mathrm{TM}}$ software. Tail length and tail intensity are the two most frequently used comet parameters, often studied concomitantly. Nevertheless, tail intensity, which points to the number of DNA breaks, is considered the most suitable indicator of DNA damage $(56,57)$, as in contrast to tail length, it continues to increase beyond a critical amount of damage. The reason why we selected total area as a parameter of interest was that, following

Table 4 Effect of hydroquinone on cell proliferation kinetics and nuclear division index (NDI) in lymphocytes treated for $24 \mathrm{~h}$, as well as in the negative and positive control samples

\begin{tabular}{|c|c|c|c|c|c|}
\hline \multirow{2}{*}{ Experimental group } & \multicolumn{4}{|c|}{ Distribution of cells according to number of nuclei } & \multirow{2}{*}{ NDI } \\
\hline & M1 & M2 & M3 & M4 & \\
\hline Hydroquinone $8.0 \mu \mathrm{g} \mathrm{mL}^{-1}$ & 159 & 834 & 7 & 0 & $1.848^{\mathrm{nc}}$ \\
\hline Negative control & 148 & 804 & 30 & 18 & 1.918 \\
\hline Positive control & 326 & 623 & 21 & 30 & $1.755^{*}$ \\
\hline
\end{tabular}

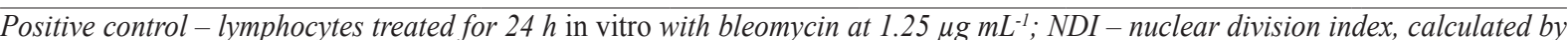
the following formula: $N D I=(M 1+2 M 2+3 M 3+4 M 4) / N$, where M1-M4 represent the number of cells with 1-4 nuclei, respectively, and $N$ is the number of cells scored; Microscopic evaluation was performed using a light microscope at $1000 \times$ magnification (oil immersion); NDI was determined by examining $2 \times 1000$ cells per sample; Statistical significance of the results was evaluated using $\chi^{2}$ test. The level of statistical significance was set at $P<0.05$. The abbreviations next to the means indicate from which groups the relevant group differs with statistical significance: ${ }^{*}$ - vs. all other samples; $n c$ - vs. negative control 

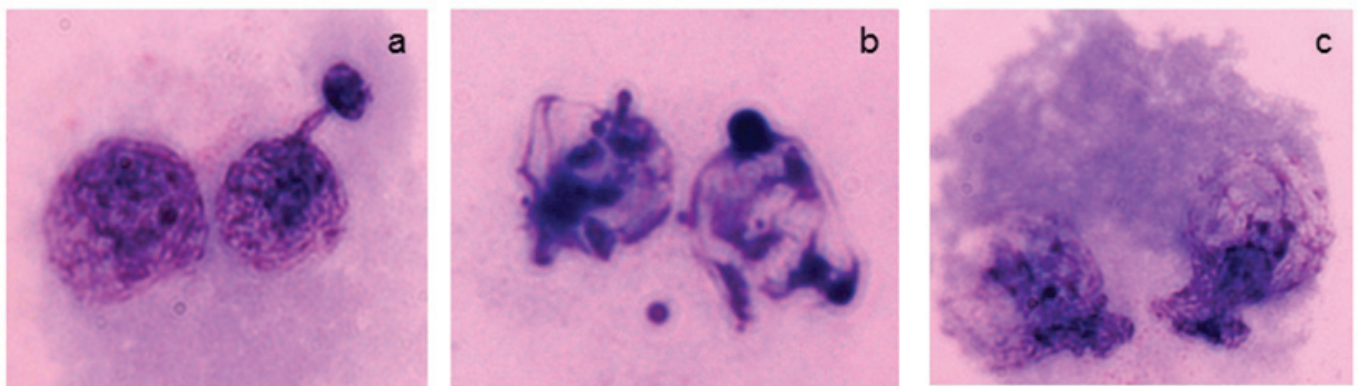

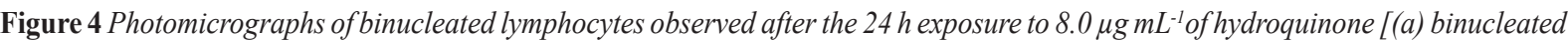
lymphocyte with nuclear bud; (b) apoptotic lymphocyte; (c) necrotic lymphocyte. Stained with Giemsa dye. Photographed under light microscope at magnification $1000 \times]$

extensive analysis of the obtained results, this parameter pointed to interesting discoveries regarding hydroquinone genotoxicity. This parameter has not frequently been involved in the evaluation of comet assay results, but the results reported in certain previous studies (59-63) confirm its value.

We found that 24 -h treatment with all three hydroquinone concentrations caused statistically significant deviations of almost all of the evaluated comet parameters. Their values were markedly decreased compared to control, which indicated specific mechanisms of hydroquinone-DNA interactions. Significantly lower DNA migration compared to control, and especially reduced total area of the comets we observed in hydroquinone-treated cells might indicate formation of cross-links, which in turn impaired denaturation of DNA. This assumption is highly possible, as formation of DNA-protein cross-links was previously documented in a study by Amin and Witz (64) in HL-60 cells exposed to $25-100 \mu \mathrm{mol} \mathrm{L}^{-1}$ of hydroquinone for $4 \mathrm{~h}$. Similarly, Luo et al. (65) in their comet assay study in HepG2 cells observed

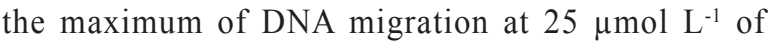
hydroquinone, while exposure to $50 \mu \mathrm{mol} \mathrm{L}^{-1}$ caused a reduction in DNA migration, which they related to the formation of DNA-protein cross-links. Considering what is known about the mechanisms of action for hydroquinone, and our own findings, we propose that exposure to hydroquinone at the two higher doses led to the formation of intra- and inter-strand DNA-DNA and DNA-protein cross-links, possibly also to formation of adducts in lymphocyte DNA, which prevented normal DNA denaturation during the alkaline denaturation step, and hindered DNA migration during electrophoresis.

As another important mechanism of hydroquinone action at DNA level, the available literature suggests the inhibition of topoisomerase II enzyme (66-68) and induction of oxidative stress $(33,65)$, resulting in a significant amount of DNA breaks. According to Andreoli et al. (33), hydroquinone produces significantly more primary DNA damage in isolated human lymphocytes than in the whole blood leukocyte population. This was primarily due to the influence of the enzymes catalase and glutathione peroxidase from erythrocytes (present in whole blood samples) on reactive hydroquinone metabolites and free radicals. Furthermore, under the influence of the enzyme myeloperoxidase [which is normally present in white blood cells (69)], hydroquinone is also converted into the more toxic reactive metabolite benzoquinone. It is known as a potent inducer of DNA adducts (70), aneugen, and potent inducer of micronuclei $(29,71)$. As mentioned before, our results suggest that the two higher hydroquinone concentrations possibly led to cross-linking and adduct formation. However, it is high likely that following exposure to the lowest tested concentration, the inhibition of topoisomerase II possibly played a more important role than cross-linking. This was sustained by the significantly higher values of all comet assay parameters measured in the sample treated with $8 \mu \mathrm{g} \mathrm{mL}^{-1}$ compared to the other two hydroquinone-treated samples. Also, findings by Frantz et al. (66) suggest that 1,4-benzoquinone inhibited topoisomerase II in in vitro conditions at concentrations of $\geq 10 \mu \mathrm{mol} \mathrm{L}{ }^{-1}$. The lowest tested hydroquinone concentration in our study corresponded to $72.6 \mu \mathrm{mol} \mathrm{L} \mathrm{L}^{-1}$, which speaks in favour of the same effects.

Considering that the alkaline comet assay cannot provide information about lymphocyte proliferation status, we extended our research to the CBMN cytome assay, one of the most comprehensive methods which enables the simultaneous study of chromosome damage, mitotic spindle apparatus damage, cell cycle kinetics, and cytotoxicity in treated cell cultures $(37,72,73)$.

Hydroquinone potency towards MN induction in human peripheral blood lymphocytes in vitro was tested in several studies so far $(28-34,74)$. The reported results are rather controversial, mainly due to different exposure conditions, duration of lymphocyte cultivation, and time of hydroquinone administration. In some studies, isolated lymphocytes were treated $(29,32,34,74)$, while other used whole blood cultures $(28,30,31)$. MN induction was observed after exposure to a wide range of hydroquinone concentrations, mainly corresponding to $1-300 \mu \mathrm{mol} \mathrm{L}{ }^{-1}$. One of the most comprehensive study designs was applied by Lippoli Doepker et al. (34), who, in an attempt to overcome the limitations of previous studies evaluated three different variations of the MN assay. They did not observe a significant increase in $\mathrm{MN}$ frequency in cultures of isolated lymphocytes treated with $12.5-200 \mu \mathrm{mol} \mathrm{L}^{-1}$ of hydroquinone. 
As mentioned in the Results section, the present study was only able to analyse preparations obtained from a sample exposed to the lowest tested hydroquinone concentration, which corresponded to $72.6 \mu \mathrm{mol} \mathrm{L}-1$. In that sample, there was no significant deviation in $\mathrm{MN}$ number compared to negative control. These findings are comparable to previous reports by Migliore and Nieri (28) and Van Hummelen and Kirsch-Volders (30), who at similar concentrations also did not record a significant increase in $\mathrm{MN}$ in the donors of blood used for testing.

We have to stress that none of the aforementioned studies evaluated the incidence of other types of cytogenetic damage covered by the "cytome" assay, as we have done. Therefore, our study added original and novel information regarding hydroquinone cyto/genotoxicity at cellular level. Particularly important was the finding regarding a significantly increased incidence of nuclear buds. Nuclear budding happens during the S-phase of a cell cycle, and it is likely that DNA repair processes resulted in the formation of excessive amplified DNA, which concentrated in the peripheral part of the nucleus and budded out (72). As mentioned before, we also found increased level of primary DNA damage, which was obviously repaired during lymphocyte growth in vitro. However, since our CBMN assay focused only at one concentration, the observed phenomenon of nuclear budding following hydroquinone treatment has to be proven further by testing a much wider range of concentrations, not only in lymphocytes, but also in other cell types in order to obtain greater insight into the mechanism of their formation after exposure to the tested compound.

Among the other endpoints studied, we also evaluated how the tested compound influences lymphocyte proliferation. Judging from the values of the nuclear division index, hydroquinone at $8 \mu \mathrm{g} \mathrm{mL}^{-1}$ (or $72.6 \mu \mathrm{mol} \mathrm{L}^{-1}$ ) significantly impaired lymphocyte cell kinetics compared to control. Our observations regarding lymphocyte proliferation are consistent with previous investigations. Lippoli Doepker et al. (34) found a block in lymphocyte division at certain hydroquinone concentrations, which was demonstrated by a decrease in the percentage of binucleated cells and the value of the division index. In their study, MN scoring was limited to concentrations of 25,50 or $75 \mu \mathrm{mol} \mathrm{L} \mathrm{L}^{-1}$ and above, depending on the blood donor. Previous studies that used whole blood in MN assay also reported mitotic delays and cytotoxicity as limiting factors to ultimately accomplish the assay, particularly at high hydroquinone concentrations. Migliore and Nieri (28) reported cytotoxicity at $200 \mu \mathrm{mol} \mathrm{L}^{-1}$, while Ferguson et al. (31) observed cytotoxicity at $>300 \mu \mathrm{mol} \mathrm{L}^{-1}$ or $400 \mu \mathrm{mol} \mathrm{L}^{-1}$, depending on the blood donor.

Up to now, millimolar concentrations of hydroquinone, comparable to two of our higher concentrations $\left(1.27 \mathrm{mmol} \mathrm{L}^{-1}\right.$ and $\left.2.54 \mathrm{mmol} \mathrm{L}^{-1}\right)$ have been tested in an MN assay only by Vian et al. (32) on isolated lymphocytes. They observed that $>1 \mathrm{mmol} \mathrm{L}^{-1}$ and $2 \mathrm{mmol} \mathrm{L}^{-1}$ (depending on the blood donor) produced cytotoxicity. This paper obtained quite comparable results regarding cytotoxicity. To find an appropriate explanation why hydroquinonetreated cells did not grow in vitro at the two higher concentrations examined in our study, we have to call to memory the mechanisms of hydroquinone toxicity clarified in previous studies. It is highly likely that in the experimental conditions of $\mathrm{MN}$ assay where whole blood was introduced into the culture, hydroquinone metabolites, benzoquinone in particular, inhibited phytohemagglutinin-stimulated lymphocyte division. A similar effect was observed for 1,4-benzoquinone by Irons et al. (75) in rat spleen lymphocytes. Lippoli Doepker et al. (34) also reported that hydroquinone caused more impairment in the growth of cultures of isolated lymphocytes used in the MN assay than in cultures established using whole blood. They assume that when whole blood was used, the presence of additional proteins and cell types stabilizes hydroquinone, diminishes the formation of oxidative species, and offers additional binding sites for its reactive metabolite benzoquinone. As a consequence, the levels of oxidative degradation products capable of interacting with the mitotic apparatus are reduced, which also reflects upon the cell cycle delays.

Furthermore, we also have to mention that another possible reason for the failed testing using the CBMN cytome assay with the two higher hydroquinone concentrations possibly stood behind its specific effect on erythrocytes. This result indicates the possibility that hydroquinone specifically disturbed erythrocyte membranes. The large amount of erythrocytes we found in cell suspensions suggests that hydroquinone (or its metabolites) prevented erythrocyte haemolysis, which is an important step in the rinsing of lymphocyte pellets during the preparation of slides for the micronucleus assay. According to Denny (76), this is very likely because benzoquinone did not cause haemolysis and instead protected erythrocytes from haemolytic stresses. As known, erythrocytes contain numerous proteins (77). Having in mind that benzoquinone leads to adduct formation in haemoglobin and albumin (78, 79), it is likely that interaction between benzoquinone and proteins prevent haemolysis. Similar effects of quinone and hydroquinone on proteins have been noted by other authors (80-82). It is possible that such an effect of hydroquinone and its metabolites present in short-term lymphocyte cultures established from whole blood in some way leads to erythrocyte stabilization and their inability to remove from the cell pellet formed after centrifugation. However, these assumptions have to be further studied.

Conclusions and future perspectives

This study is to a certain extent limited by the fact that it was accomplished on an in vitro model, which means that the results cannot be directly extrapolated to real in vivo conditions. Although the lymphocyte model is common in genetic toxicology testing and has been recently used in studies employing similar methods as ours $(13,14,17)$, the fact that human lymphocytes represent a population of 
resting cells that do not possess intrinsic metabolic activation suggests the need for further studies using other appropriate cell lines to unequivocally prove the obtained results. Lastly, we are aware that testing a much wider range of hydroquinone concentrations and using more sophisticated methods (e.g., specific modifications of the comet assay and more accurate methods for the detection of apoptosis) would provide a more accurate explanation of the observed effects, but at the moment this was not possible due to various technical and financial constraints.

When the results obtained by testing of hydroquinone in vitro are considered in their entirety, the genotoxic risk of exposure to its lowest concentration, which is far above the amount of hydroquinone produced by the metabolism following an uptake of the maximum daily allowable concentration of arbutin, is also relatively low. On the other hand, exposure to the two higher hydroquinone concentrations, which produced more detrimental effects in vitro, is not likely to be achieved in actual in vivo conditions. Taken together, in spite of all of the limitations, our findings should provide valuable information regarding hydroquinone toxicity and represent a solid base for our future investigations.

\section{Acknowledgements}

This study was financially supported by the Mali Lošinj Tourist Board and Institutional funding provided by the Ministry of Science and Education of the Republic of Croatia.

\section{Conflicts of interest}

The authors declare no conflicts of interest.

\section{REFERENCES}

1. Enguita FJ, Leitão AL. Hydroquinone: Environmental pollution, toxicity, and microbial answers. BioMed Res Int 2013;2013:542168. doi: 10.1155/2013/542168

2. DeCaprio AP. The toxicology of hydroquinone-relevance to occupational and environmental exposure. Crit Rev Toxicol 1999:29:283-330. doi: 10.1080/10408449991349221

3. Schindler G, Patzak U, Brinkhaus B, von Nieciecki A, Wittig J, Krähmer N, Glöckl I, Veit M. Urinary excretion and metabolism of arbutin after oral administration of Arctostaphylos uvae ursi extract as film-coated tablets. J Clin Pharmacol2002;42:920-7. doi: 10.1177/009127002401102740

4. European Medicines Agency. Assessment report on Arctostaphylos uva-ursi (L.) Spreng., folium, 2012 [displayed 14 November 2017]. Available at http://www.ema.europa eu/docs/en GB/document library/Herbal - HMPC assessment report/2011/07/WC500108750.pdf

5. Jurica K, Gobin I, Kremer D, Vitali Čepo D, Jurišić Grubešić R, Brčić Karačonji I, Kosalec I. Arbutin and its metabolite hydroquinone as main factors in the antimicrobial effect of strawberry tree (Arbutus unedo L.) leaves. J Herb Med 2017;8:17-23. doi: 10.1016/j.hermed.2017.03.006
6. Blaut M, Braune A, Wunderlich S, Sauer P, Schneider H, Glatt H. Mutagenicity of arbutin in mammalian cells after activation by human intestinal bacteria. Food Chem Toxicol 2006;44:1940-7. doi: 10.1016/j.fct.2006.06.015

7. United States - Food and Drug Administration (US-FDA). Hydroquinone [CAS 123-31-9] Supporting Information for Toxicological Evaluation by the National Toxicology Program, 2009 [displayed 14 November 2017]. Available at https://ntp.niehs.nih.gov/ntp/noms/support_docs/ hydroquinone_may2009.pdf

8. de Arriba SG, Naser B, Nolte KU. Risk assessment of free hidroquinone derived from Arctostaphylos Uva-ursi folium herbal preparations. Int J Toxicol 2013;32:442-56. doi: $10.1177 / 1091581813507721$

9. Roza L, de Vogel N, van Delft JHM. Lack of clastogenic effects in cultured human lymphocytes treated with hydroquinone. Food Chem Toxicol 2003;41:1299-305. doi: 10.1016/S0278-6915(03)00118-2

10. Whysner J, Verna L, English JC, Williams GM. Analysis of studies related to tumorigenicity induced by hydroquinone. Regul Toxicol Pharmacol 1995;21:158-76. doi: 10.1006/ rtph.1995.1020

11. IARC. Overall evaluations of carcinogenicity: an updating of IARC Monographs volumes 1 to 42. IARC Monogr Eval Carcinog Risks Hum 1987;Suppl 7:1-440.

12. Souček P, Ivan G, Pavel S. Effect of the microsomal system on interconversions between hydroquinone, benzoquinone, oxygen activation, and lipid peroxidation. Chem Biol Interact 2000;126:45-61. doi: 10.1016/S0009-2797(00)00155-1

13. Turkez H, Aydın E, Geyikoglu F, Cetin D. Genotoxic and oxidative damage potentials in human lymphocytes after exposure to terpinolene in vitro. Cytotechnology 2015;67:40918. doi: 10.1007/s10616-014-9698-z

14. Branica G, Mladinić M, Omanović D, Želježić D. An alternative approach to studying the effects of $\mathrm{ZnO}$ nanoparticles in cultured human lymphocytes: combining electrochemistry and genotoxicity tests. Arh Hig Rada Toksikol 2016;67:277-88. doi: 10.1515/aiht-2016-67-2910

15. Valencia-Quintana R, Gómez-Arroyo S, Sánchez-Alarcón S, Milić M, Olivares JLG, Waliszewski SM, Cortés-Eslava J, Villalobos-Pietrini R, Calderón-Segura ME. Assessment of genotoxicity of Lannate $-90^{\circledR}$ and its plant and animal metabolites in human lymphocyte cultures. Arh Hig Rada Toksikol 2016a;67:116-25. doi: 10.1515/aiht-2016-67-2763

16. Valencia-Quintana R, Gómez-Arroyo S, Sánchez-Alarcón S, Milić M, Olivares JLG, Waliszewski SM, Cortés-Eslava J, Villalobos-Pietrini R, Calderón-Segura ME. Genotoxic effects of the carbamate insecticide Pirimor- $50^{\circledR}$ in Vicia faba root tip meristems and human lymphocyte culture after direct application and treatment with its metabolic extracts. Arh Hig Rada Toksikol 2016b;67:266-76. doi: 10.1515/aiht-201667-2809

17. Petrović, S, Vasić V, Mitrović T, Lazović S, Leskovac, A. The impact of concentration and administration time on the radiomodulating properties of undecylprodigiosin in vitro. Arh Hig Rada Toksikol 2017;68:1-8. doi: 10.1515/aiht-201768-2897

18. Sreejaya SB, Archana D, Santhy KS. Genoprotective effects of Acorus calamus rhizome against DNA damage in peripheral blood lymphocytes. Int J Green Pharm 2017;11(Suppl):S108-11. doi: 10.22377/ijgp.v11i01.880 
19. Gasiorowski K, Brokos B, Kulma A, Ogorzałek A, Skórkowska K. A comparison of the methods applied to detect apoptosis in genotoxically-damaged lymphocytes cultured in the presence of four antimutagens. Cell Mol Biol Lett 2001;6:141-59. PMID: 11544636

20. Kopjar N, Želježić D, Kosalec I, Bakmaz M, Jug M. Cytoprotectivity of plant extracts on doxorubicin and irinotecan-treated human peripheral blood lymphocytes. Planta Med 2007;73:507. doi: 10.1055/s-2007-987287

21. Benković V, Knežević AH, Oršolić N, Bašić I, Ramić S, Viculin T, Knežević F, Kopjar N. Evaluation of radioprotective effects of propolis and its flavonoid constituents: in vitro study on human white blood cells. Phytother Res 2009;23:1159-68. doi: 10.1002/ptr.2774

22. Benković V, Kopjar N, Horvat Knežević A, Đikić D, Bašić I, Ramić S, Viculin T, Knežević F, Oršolić N. Evaluation of radioprotective effects of propolis and quercetin on human white blood cells in vitro. Biol Pharm Bull 2008;31:1778-85. doi: 10.1248/bpb.31.1778

23. Prasad NR, Jeyanthimala K, Ramachandran S. Caffeic acid modulates ultraviolet radiation-B induced oxidative damage in human blood lymphocytes. J Photochem Photobiol B 2009;95:196-203. doi: 10.1016/j.jphotobiol.2009.03.007

24. Rusak G, Piantanida I, Masić L, Kapuralin K, Durgo K, Kopjar N. Spectrophotometric analysis of flavonoid-DNA interactions and DNA damaging/protecting and cytotoxic potential of flavonoids in human peripheral blood lymphocytes. Chem Biol Interact 2010;188:181-9. doi: 10.1016/j.cbi.2010.07.008

25. Boligon AA, Sagrillo MR, Machado LF, de Souza Filho O, Machado MM, da Cruz IB, Athayde ML. Protective effects of extracts and flavonoids isolated from Scutia buxifolia Reissek against chromosome damage in human lymphocytes exposed to hydrogen peroxide. Molecules 2012;17:5757-69. doi: $10.3390 /$ molecules 17055757

26. Grace Nirmala J, Evangeline Celsia S, Swaminathan A, Narendhirakannan RT, Chatterjee S. Cytotoxicity and apoptotic cell death induced by Vitis vinifera peel and seed extracts in A431 skin cancer cells. Cytotechnology 2017. doi: 10.1007/s10616-017-0125-0

27. Sigma-Aldrich. Product Information Histopaque ${ }^{\circledR}-1077$ [displayed 24 October 2017]. Available at https://www. sigmaaldrich.com/content/dam/sigma-aldrich/docs/Sigma/ Product_Information_Sheet/1/10771pis.pdf

28. Migliore L, Nieri M. Evaluation of twelve potential aneuploidogenic chemicals by the in vitro human lymphocyte micronucleus assay. Toxicol In Vitro 1991;5:325-36. doi: 10.1016/0887-2333(91)90009-3

29. Robertson ML, Eastmond DA, Smith MT. Two benzene metabolites, catechol and hydroquinone, produce a synergistic induction of micronuclei and toxicity in cultured human lymphocytes. Mutat Res 1991;249:201-9. doi: 10.1016/0027-5107(91)90147-G

30. Van Hummelen P, Kirsch-Volders M. Analysis of eight known or suspected aneugens by the in vitro human lymphocyte micronucleus test. Mutagenesis 1992;7:447-55. doi: 10.1093/ mutage/7.6.447

31. Ferguson LR, Morcombe P, Triggs CN. The size of cytokinesis-blocked micronuclei in human peripheral blood as a measure of aneuploidy induction by Set A compounds in the EEC trial. Mutat Res 1993;287:101-12. doi: 10.1016/0027-5107(93)90149-A

32. Vian L, Van Hummelen P, Bichet N, Gouy D, Kirsch-Volders $\mathrm{M}$. Evaluation of hydroquinone and chloral hydrate on the in vitro micronucleus test on isolated lymphocytes. Mutat Res 1995;334:1-7. doi: 10.1016/0165-1161(95)90024-1

33. Andreoli C, Rossi S, Leopardi P, Crebelli R. DNA damage by hydroquinone in human white blood cells: analysis by alkaline single-cell gel electrophoresis. Mutat Res 1999;438:37-45. doi: 10.1016/S1383-5718(98)00160-0

34. Lippoli Doepker C, Wonder Dumont K, O'Donoghue J, English JC. Lack of induction of micronuclei in human peripheral blood lymphocytes treated with hydroquinone. Mutagenesis 2000;15:479-87. doi: 10.1093/mutage/15.6.479

35. Joksić G, Stanković M, Novak A. Antibacterial medicinal plants Equiseti herba and Ononidis radix modulate micronucleus formation in human lymphocytes in vitro. J Environ Pathol Toxicol Oncol 2003;22:41-8. doi: 10.1615/ JEnvPathToxOncol.v22.i1.40

36. National Toxicology Program. Chemical Information Review Document for Arbutin [CAS No. 497-76-7] and Extracts from Arctostaphylos uva-ursi. Natl Toxicol Progr 2006 [displayed 15 November 2017]. Available at https://ntp.niehs.nih.gov/ ntp/htdocs/chem_background/exsumpdf/arbutin_508.pdf

37. Fenech $\mathrm{M}$. The in vitro micronucleus technique. Mutat Res 2000;455:81-95. doi: 10.1016/S0027-5107(00)00065-8

38. Duke RC, Cohen JJ. Morphological and biochemical assays of apoptosis. In: Coligan JE, Kruisbeal AM, editors. Current protocols in immunology. New York: John Willey and Sons; 1992. p. 1-3.

39. Singh NP, McCoy MT, Tice RR, Schneider EL. A simple technique for quantitation of low levels of DNA damage in individual cells. Exp Cell Res 1988;175:184-91. doi: 10.1016/0014-4827(88)90265-0

40. Fenech M, Morley AA. Measurement of micronuclei in lymphocytes. Mutat Res 1985;147:29-36. doi: 10.1016/01651161(85)90015-9

41. Fenech M, Chang WP, Kirsch-Volders M, Holland N, Bonassi S, Zeiger, E. HUMN project: detailed description of the scoring criteria for the cytokinesis-block micronucleus assay using isolated human lymphocyte cultures. Mutat Res 2003;534:65-75. doi: 10.1016/S1383-5718(02)00249-8

42. Eastmond DA, Tucker JD. Identification of aneuploidyinducing agents using tokinesis-blocked human lymphocytes and an anti-kinetochore antibody. Environ Mol Mutagen 1989;13:34-43. doi: 10.1002/em.2850130104

43. McDonald TA, Holland NT, Skibola C, Duramad P, Smith MT. Hypothesis: phenol and hydroquinone derived mainly from diet and gastrointestinal flora activity are causal factors in leukemia. Leukemia 2001;15:10-20. PMID 11243376

44. Jurica K, Brčić Karačonji I, Šegan S, Milojković Opsenica D, Kremer D. Quantitative analysis of arbutin and hydroquinone in strawberry tree (Arbutus unedo L., Ericaceae) leaves by gas chromatography-mass spectrometry. Arh Hig Rada Toksikol 2015;66:197-202. doi: 10.1515/aiht2015-66-2696

45. Wen AH, Choi MK, Kim DD. Formulation of liposome for topical delivery of arbutin. Arch Pharm Res 2006;29:1187-92. doi: 10.1007/BF02969312

46. Thongchai W, Liawruangrath B, Liawruangrath S. Highperformance liquid chromatographic determination of arbutin 
in skin-whitening creams and medicinal plant extracts. J Cosmet Sci 2007;58:35-44. doi: 10.1111/j.1468-2494. 2007.00391_4.x

47. Zhu W, Gao J. The use of botanical extracts as topical skinlightening agents for the improvement of skin pigmentation disorders. J Investig Dermatol Symp Proc 2008;13:20-4. doi: 10.1038/jidsymp.2008.8

48. Gillbro JM, Olsson MJ. The melanogenesis and mechanisms of skin-lightening agents - existing and new approaches. Int J Cosmet Sci 2011;33:210-21. doi: 10.1111/j.1468-2494. 2010.00616.x

49. Yusuf, I, Fruman DA. Regulation of quiescence in lymphocytes. Trends Immunol 2003;24:380-6. doi: 10.1016/ S1471-4906(03)00141-8

50. Yao G. Modelling mammalian cellular quiescence. Interface Focus 2014;4:20130074. doi: 10.1098/rsfs.2013.0074

51. Hiraku Y, Kawanishi S. Oxidative DNA damage and apoptosis induced by benzene metabolites. Cancer Res 1996;56:5172-8. PMID 8912853

52. Inayat-Hussain SH, Winski SL, Ross D. Differential involvement of caspases in hydroquinone-induced apoptosis in human leukemic hl-60 and jurkat cells. Toxicol Appl Pharmacol 2001;175:95-103. doi: 10.1006/taap.2001.9221

53. Terasaka H, Morshed SR, Hashimoto K, Sakagami H, Fujisawa S. Hydroquinone-induced apoptosis in HL-60 cells. Anticancer Res 2005;25:161-70. PMID 15816534

54. Yang EJ, Lee JS, Yun CY, Kim IS. The pro-apoptotic effect of hydroquinone in human neutrophils and eosinophils. Toxicol in Vitro 2011;25:131-7. doi: 10.1016/j.tiv.2010.10.004

55. Lee JS, Yang EJ, Kim IS. Hydroquinone-induced apoptosis of human lymphocytes through caspase $9 / 3$ pathway. Mol Biol Rep 2012;39:6737-43. doi: 10.1007/s11033-012-1498-y

56. Olive PL. DNA damage and repair in individual cells: applications of the comet assay in radiobiology. Int J Radiat Biol 1999;75:395-405. doi: 10.1080/095530099140311

57. Collins AR. The comet assay for DNA damage and repair: principles, applications, and limitations. Mol Biotechnol 2004;26:249-61. doi: 10.1385/MB:26:3:249

58. Azqueta A, Slyskova J, Langie SA, O'Neill Gaivão I, Collins A. Comet assay to measure DNA repair: approach and applications. Front Genet 2014;5:288. doi: 10.3389/ fgene.2014.00288

59. Andreoli C, Leopardi P, Crebelli R. Detection of DNA damage in human lymphocytes by alkaline single cell gel electrophoresis after exposure to benzene or benzene metabolites. Mutat Res 1997;377:95-104. doi: 10.1016/ S0027-5107(97)00065-1

60. Buschfort C, Muller M, Seeber S, Rajewsky MF, Thomale J. DNA excision repair profiles of normal and leukemic human lymphocytes: functional analysis at the single-cell level. Cancer Res 1997;57:651-8. PMID 9044842

61. Thomale J, Müller MR, Buschfort C, Seeber S, Rajewsky MF. Alterations in DNA repair: Implications for leukemia cell biology. In: Hiddemann W, Büchner T, Wörmann B, editors. Acute leukemias VII. Haematology and blood transfusion/hämatologie und bluttransfusion. Vol 39. Berlin: Heidelberg:Springer; 1998. p. 3-12.

62. Benítez-Bribiesca L, Sánchez P, Toledo J, Peñarroja R, Flores $\mathrm{M}$, Sosa J. Differential staining of DNA strand breaks in dried comet assay slides. J Histochem Cytochem 2001;49:921-2. doi: $10.1177 / 002215540104900713$
63. Buschfort-Papewalis C, Moritz T, Liedert B, Thomale J. Down-regulation of DNA repair in human CD34(+) progenitor cells corresponds to increased drug sensitivity and apoptotic response. Blood 2002;100:845-53. doi: 10.1182/ blood-2002-01-0022

64. Amin RP, Witz G. DNA-protein crosslink and DNA strand break formation in HL-60 cells treated with trans,transmuconaldehyde, hydroquinone and their mixtures. Int J Toxicol 2001;20:69-80. doi: 10.1080/10915810151115173

65. Luo L, Jiang L, Geng C, Cao J, Zhong L. Hydroquinoneinduced genotoxicity and oxidative DNA damage in HepG2 cells. Chem Biol Interact 2008;173:1-8. doi: 10.1016/j. cbi.2008.02.002

66. Frantz CE, Chen H, Eastmond DA. Inhibition of human topoisomerase II in vitro by bioactive benzene metabolites. Environ Health Perspect 1996;104(Suppl 6):1319-23. PMCID: PMC1469756

67. Fung J, Hoffmann MJ, Kim DD, Snyder R. Inhibition of topoisomerase II in 32D.3(G) cells by hydroquinone is associated with cell death. J Appl Toxicol 2004;24:183-8. doi: $10.1002 /$ jat. 960

68. Lindsey RH, Bender RP, Osheroff N. Effects of benzene metabolites on DNA cleavage mediated by human topoisomerase II alpha: 1,4-hydroquinone is a topoisomerase II poison. Chem Res Toxicol 2005;18:761-70. doi: 10.1021/ tx049659z

69. Kettle AJ, Winterbourn CC. Oxidation of hydroquinone by myeloperoxidase. Mechanism of stimulation by benzoquinone. J Biol Chem 1992;267:8319-24. PMID 1314822

70. Chenna A, Hang B, Rydberg B, Kim E, Pongracz K, Bodel WJ, Singer B. The benzene metabolite $p$-benzoquinone forms adducts with DNA bases that are excised by a repair activity from human cells that differs from an ethenoadenine glycosylase. Proc Natl Acad Sci USA 1995;92:5890-4. doi: 10.1073/pnas.92.13.5890

71. Do Céu Silva M, Gaspar J, Duarte Silva I, Leão D, Rueff J. Mechanisms of induction of chromosomal aberrations by hydroquinone in V79 cells. Mutagenesis 2003;18:491-6. doi: 10.1093/mutage/geg029

72. Fenech M. Cytokinesis-block micronucleus assay evolves into a "cytome" assay of chromosomal instability, mitotic dysfunction and cell death. Mutat Res 2006;600:58-66. doi: 10.1016/j.mrfmmm.2006.05.028

73. Fenech M, Kirsch-Volders M, Natarajan AT, Surralles J, Crott JW, Parry J, Norppa H, Eastmond DA, Tucker JD, Thomas P. Molecular mechanisms of micronucleus, nucleoplasmic bridge and nuclear bud formation in mammalian and human cells. Mutagenesis 2011;26:125-32. doi: 10.1093/mutage/ geq052

74. Yager JW, Eastmond DA, Robertson ML, Paradisin WM, Smith MT. Characterization of micronuclei induced in human lymphocytes by benzene metabolites. Cancer Res 1990;90:393-9. PMID 2295079

75. Irons RD, Neptun DA, Pfeifer RW. Inhibition of lymphocyte transformation and microtubule assembly by quinone metabolites of benzene. Evidence for a common mechanism. J Reticuloendothel Soc 1981;30: 359-72. PMID 7320996

76. Denny BJ. Quinones: reactions with hemoglobin, effects within erythrocytes and potential for antimalarial 
development. [PhD thesis]. Cleveland OH, USA: Case Western Reserve University; 1986.

77. Kakhniashvili DG. The human erythrocyte proteome: analysis by ion trap mass spectrometry. Mol Cell Proteomics 2004;3:501-9. doi: 10.1074/mcp.M300132-MCP200

78. McDonald TA, Waidyanatha S, Rappaport SM. Measurement of adducts of benzoquinone with hemoglobin and albumin Carcinogenesis 1993;14:1927-32. doi: 10.1093/ carcin/14.9.1927

79. Waidyanatha S, Yeowell-O'Connell K, Rappaport SM. A new assay for albumin and hemoglobin adducts of 1,2- and 1,4-benzoquinones. Chem Biol Interact 1998;115:117-39. PMID 9826945
80. Boatman RJ, English JC, Perry LG, Fiorica LA. Covalent protein adducts of hydroquinone in tissues from rats: identification and quantitation of sulfhydryl-bound forms. Chem Res Toxicol 2000;13:853-60. doi: 10.1021/tx000037x

81. Bittner S. When quinones meet amino acids: chemical, physical and biological consequences. Amino Acids 2006;30:205-24. doi: 10.1007/s00726-005-0298-2

82. Yamauchi A, Hatanaka Y, Muro T, Kobayashi O. Enzyme-free quinone crosslinking reaction for proteins: a macromolecular characterization study using gelatin. Macromol Biosci 2009;9:875-83. doi: 10.1002/mabi.200900032

\section{Istraživanje citotoksičnih, genotoksičnih i citogenetičkih učinaka hidrokinona na ljudskim limfocitima periferne krvi u uvjetima in vitro}

Cilj ovog istraživanja bio je proučiti mehanizme toksičnosti hidrokinona i odnose između njegovih citotoksičnih, genotoksičnih i citogenetičkih učinaka na ljudskim limfocitima periferne krvi izloženima koncentracijama 8, 140 i 280 $\mu \mathrm{g} \mathrm{mL} \mathrm{m}^{-1}$ tijekom 24 sata. Posljedice izlaganja testiranom spoju istražene su primjenom testa za otkrivanje stanica u apoptozi i nekrozi, komet-testa u alkalnim uvjetima i tzv. cytome inačice citohalazinom blokiranog mikronukleus-testa. Istražene koncentracije hidrokinona izazvale su relativno nisku citotoksičnost u limfocitima, koji većinom ugibaju apoptozom. Međutim, pri istim koncentracijama primjenom komet-testa uočene su značajne promjene u razinama primarnih oštećenja DNA u odnosu na kontrolu. Statistički značajno snižene vrijednosti svih parametara komet-testa u odnosu na kontrolne stanice upućuju na specifične mehanizme međudjelovanja hidrokinona i DNA. Dobiveni rezultati upućuju na mogućnost nastanka ukriženih veza u molekuli DNA (engl. cross-linking) i nastanak adukata u DNA nakon izloženosti dvjema višim koncentracijama hidrokinona, a povišene vrijednosti lomova u DNA, uočene nakon izlaganja najnižoj ispitanoj koncentraciji, upućuju na veći značaj oksidacijskih oštećenja i utjecaj mehanizama povezanih s inhibicijom enzima topoizomeraze II. Pri koncentraciji $8 \mu \mathrm{g} \mathrm{mL}{ }^{-1}$ hidrokinon ne izaziva značajan porast broja mikronukleusa. Koncentracije 140 i $280 \mu \mathrm{g} \mathrm{mL}^{-1}$ potpuno koče diobu limfocita, a ujedno izazivaju i stabilizaciju membrana eritrocita, sprječavajući njihovu lizu. Dva dobivena rezultata značajan su doprinos postojećim saznanjima o toksičnosti hidrokinona: (I.) Ovo je prvo istraživanje u kojem je izmjereno smanjenje ukupne površine kometa limfocitne DNA nakon izlaganja hidrokinonu; (II.) Ovo je prvo istraživanje u kojem je primijenjena cytome inačica mikronukleus-testa, kojom smo dokazali da izloženost čak i vrlo niskim koncentracijama hidrokinona dovodi do značajno povišene učestalosti nastanka jezgrinih pupova u limfocitima. Uzevši u obzir ograničenja limfocita kao modela, ponajprije nedostatak unutarnje metaboličke aktivacije, za nedvojbenu potvrdu dobivenih rezultata predlažemo nastavak istraživanja i na drugim prikladnim modelima staničnih linija.

KLJUČNE RIJEČI: apoptoza; citohalazinom blokiran mikronukleus cytome test; jezgrini pupovi; primarna oštećenja DNA; ukupna površina kometa 